\title{
IMPACT OF THERMAL TREATMENT OF MIXTURES OF SEWAGE SLUDGE AND PLANT MATERIAL ON SELECTED CHEMICAL PROPERTIES AND Vibrio fischeri RESPONSE
}

\author{
WPŁYW TERMICZNEGO PRZEKSZTAŁCENIA MIESZANIN OSADU \\ ŚCIEKOWEGO Z MATERIAŁAMI ROŚLINNYMI NA WYBRANE \\ WŁAŚCIWOŚCI CHEMICZNE ORAZ REAKCJĘ Vibrio fischeri
}

\begin{abstract}
The aim of the research was to evaluate the effect of temperature during the treatment process as well as the effect of adding plant materials to sewage sludge on selected chemical properties and Vibrio fischeri response. The mixtures were placed in a chamber furnace, under airless conditions. Two temperature procedures were applied: 300 and $600^{\circ} \mathrm{C}$; the exposure time in both cases was 15 minutes. Thermal treatment of sewage sludge without a plant component is not well-founded and may cause an increase in concentration of trace elements. Using the temperature of $300^{\circ} \mathrm{C}$ caused significantly lower changes in the contents of total forms of trace elements than using the temperature of $600^{\circ} \mathrm{C}$. The metals extracted from the studied mixtures were not toxic for the Vibrio fischeri. In the case of the fractional composition of humic compounds, thermal treatment of mixtures of sewage sludge and plant materials is not beneficial in terms of labile fractions, but it had a beneficial effect on stabilizing the durable bonds between $\mathrm{C}$ compounds in those mixtures.
\end{abstract}

Keywords: biochar, thermal treatment, heavy metals, carbon compounds, Vibrio fischeri

\section{Introduction}

In recent years an increasing problem associated with the need to dispose of sewage sludge has been observed [1]. Management of municipal waste is one of the most challenging problems in many urban municipalities due to increasing waste volume with limited disposal areas, energy-consuming and high-cost treatment processes for disposal. The amount of sewage sludge deposited and stored temporarily at treatment plants or used in land reclamation, including for agricultural purposes, has decreased $[2,3]$.

Depending on the origin, sewage sludge is difficult to recycle because it is characterized by significant amounts of heavy metals, organic toxins and pathogenic microorganisms that could constitute a contamination source for soil $[4,5]$. Apart from the conventional methods used for sewage sludge disposal (such as landfilling, use in

\footnotetext{
${ }^{1}$ Department of Agricultural and Environmental Chemistry, University of Agriculture, al. A. Mickiewicza 21, 31-120 Kraków, Poland, phone +48 1266243 46, fax +48 126624341

*Corresponding author: monika6_mierzwa@wp.pl,monika.mierzwa@urk.edu.pl
} 
agriculture or incineration), using this product to obtain biochar can be the answer to the current problems related to sewage sludge reuse [2, 5-7].

As a result of thermal treatment of sewage sludge, multidirectional changes in chemical compounds contained in these materials take place. Process parameters such as temperature, treating time, heating rate and feedstock particle size concern not only physical parameters of the material subjected to treatment, but also trace elements, humic compounds, and in consequence determine the potential use of biochar in agriculture [8-12].

Most of the research on thermal treatment of sewage sludge has focused on energy and fuel quality [13], carbon stability of biochar materials [14, 15], improvement of soil biological properties and soil quality [16], or on the effect of temperature on the final properties of biochar [11]. However, this research is predominantly focused on the analysis of biochar made from sewage sludge with varying properties and different temperatures. In such a case, characteristics of sewage sludge biochar are not known.

Taking into account the possibility of using such a type of materials, the issue of natural use can be considered, and in this aspect it is important to assess the forms of trace elements, particularly the most mobile ones which can easily get dispersed in the environment. Moreover, assessment of the impact the product of thermal treatment has on living organisms is also important. On the other hand, taking carbon sequestration into account, it is important to assess the impact of the process on the stability of humic compounds $[11,17,18]$.

It needs to be pointed out that, depending on temperature, a loss in organic matter takes place during thermal treatment of sewage sludge, which leads to an increase in the content of mineral components, including trace elements [11]. Better effects, not only in terms of the environment, but also in terms of technology, can be achieved after mixing sewage sludge with plant waste materials, such as cereal straw, sawdust or bark. The addition of these materials leads to dilution of the content of trace elements, and it also improves the conditions for conducting the thermal process by influencing the structure of the treated mass [19].

As other authors have shown, biochar obtained from thermally treated mixtures of sewage sludge and plant waste may be considered to be a fertilizing material which, due to its beneficial physical properties, may be used environmentally [10, 12, 20-22]. However, there are also some reports evaluating the potential negative effects of biochar use [23, 24]. Therefore, before such a material is used for environmental purposes, one should evaluate the possibility of occurrence of adverse effects of its use [25].

The aim of the research was to evaluate the effect of temperature during the treatment process as well as the effect of adding plant material to sewage sludge on selected chemical properties and Vibrio fischeri response.

\section{Materials and methods}

\section{Characteristics of materials used in the research}

The starting material for the research consisted of anaerobically stabilized, dehydrated sewage sludge collected at the Sewage Treatment Plant in Krakow. The treatment plant is equipped with a system of mechanical-biological sewage treatment. The plant materials used in the research came from the area of the Malopolska region (southern Poland). 
Selected chemical properties of the sewage sludge and the plant materials are presented in Tables 1 and 2.

Table 1

The selected properties of materials used in the experiment

\begin{tabular}{|c|c|c|c|}
\hline \multirow{2}{*}{ Material } & Dry matter & Organic matter & Ash \\
\cline { 2 - 4 } & {$\left[\mathrm{g} \cdot \mathrm{kg}^{-1}\right]$} & \multicolumn{2}{|c|}{$\left[\mathrm{g} \cdot \mathrm{kg}^{-1} \mathrm{~d} . \mathrm{m}.\right]$} \\
\hline Wheat straw (WS) & $990 \pm 24$ & $968 \pm<1$ & $32 \pm<1$ \\
\hline Sawdust (S) & $989 \pm 24$ & $993 \pm<1$ & $7 \pm<1$ \\
\hline Bark (B) & $988 \pm 23$ & $553 \pm 3$ & $447 \pm 3$ \\
\hline Sewage sludge (SS) & $236 \pm 6$ & $493 \pm 4$ & $507 \pm 4$ \\
\hline
\end{tabular}

Each value represents the mean of three replicates \pm standard deviation $(S D)$

Table 2

The content of trace elements in materials used in the experiment

\begin{tabular}{|c|c|c|c|c|c|c|}
\hline \multirow{2}{*}{ Material } & $\mathrm{Cr}$ & $\mathbf{N i}$ & $\mathbf{C u}$ & Zn & Cd & $\mathbf{P b}$ \\
\hline & \multicolumn{6}{|c|}{$\left[\mathrm{mg} \cdot \mathrm{kg}^{-1}\right.$ d.m. $]$} \\
\hline Wheat straw & $1.85 \pm 0.10$ & $1.16 \pm 0.08$ & $2.83 \pm 0.10$ & $36.0 \pm 0.2$ & $0.53 \pm 0.01$ & $1.41 \pm 0.04$ \\
\hline Sawdust & $1.39 \pm 0.10$ & $0.86 \pm 0.01$ & $2.25 \pm 0.40$ & $17.3 \pm 0.3$ & $0.39 \pm 0.01$ & $2.76 \pm 0.12$ \\
\hline Bark & $7.99 \pm 0.27$ & $3.92 \pm 0.06$ & $7.19 \pm 1.00$ & $49.0 \pm 3.8$ & $0.48 \pm 0.00$ & $10.6 \pm 0.3$ \\
\hline $\begin{array}{l}\text { Sewage } \\
\text { sludge }^{1)}\end{array}$ & $420 \pm 16$ & $64.7 \pm 0.60$ & $330 \pm 5.5$ & $1751 \pm 69$ & $2.17 \pm 0.16$ & $58.9 \pm 2.55$ \\
\hline $\begin{array}{l}\text { Sewage } \\
\text { sludge }^{2)}\end{array}$ & n.d. & $5.01 \pm 0.66$ & $3.08 \pm 0.18$ & $84.1 \pm 8.8$ & $0.06 \pm 0.01$ & $0.20 \pm 0.01$ \\
\hline
\end{tabular}

n.d. - not determined; ${ }^{1)}$ total forms, ${ }^{2)}$ water soluble forms. Each value represents the mean of three replicates $\pm S D$

\section{Preparation of the mixtures and the process of their thermal treatment}

In order to improve physical properties, the sewage sludge was mixed with the plant materials. The preparation procedure of the mixtures was presented in the study of Gondek et al. [26]. The contents of dry matter and of selected trace elements in the mixtures that were not treated are presented in Table 3.

The dry matter and ash in mixtures before treatment and residue after thermal treatment of mixtures

\begin{tabular}{|c|c|c|c|c|}
\hline \multirow{2}{*}{ Material* } & Dry matter & Ash & $\begin{array}{c}\text { Residue } \\
\text { at } \mathbf{3 0 0}^{\circ} \mathbf{C}\end{array}$ & $\begin{array}{c}\text { Residue } \\
\text { at } \mathbf{6 0 0}^{\circ} \mathbf{C}\end{array}$ \\
\cline { 2 - 5 } & {$\left[\mathrm{g} \cdot \mathrm{kg}^{-1}\right]$} & {$\left[\mathrm{g} \cdot \mathrm{kg}^{-1} \mathrm{~d} . \mathrm{m}.\right]$} & \multicolumn{2}{|c|}{$[\%]$} \\
\hline $\mathrm{SS}+\mathrm{B}$ & $351 \pm 6$ & $406 \pm 12$ & $71.4 \pm 1.0$ & $61.4 \pm 4.0$ \\
\hline $\mathrm{SS}+\mathrm{WS}$ & $312 \pm 9$ & $206 \pm 5$ & $53.5 \pm 1.3$ & $43.1 \pm 1.0$ \\
\hline $\mathrm{SS}+\mathrm{S}$ & $302 \pm 7$ & $225 \pm 9$ & $53.0 \pm 1.4$ & $42.3 \pm 1.0$ \\
\hline $\mathrm{CV}$ & 8 & 32 & 17 & 22 \\
\hline
\end{tabular}

* see Materials and methods. Each value represents the mean of three replicates \pm standard deviation

Thermal processing of mixtures of sewage sludge with various plant additions was conducted under laboratory conditions, at a station designed for thermal processing of biomass at reduced air access (1-2\%) [27]. Two temperature procedures were applied: 300 and $600^{\circ} \mathrm{C}$; the exposure time in both cases was 15 minutes (sample weight was $500 \mathrm{~g} \mathrm{~d}$.m.). Selection of the temperature of $300^{\circ} \mathrm{C}$ derived from the intention of using the product (biochar) in nature. It is assumed that the pyrolysis temperature should be $300^{\circ} \mathrm{C}$ when using biochar for natural, including agricultural, purposes. The material obtained in 
this way has higher cation exchange capacity and higher content of stable carbon [28, 29]. On the other hand, the temperature of $600^{\circ} \mathrm{C}$ was selected with the aim to verify the hypothesis that higher temperatures are more effective in removing organic compounds, e.g. PAHs. According to Guilloteau et al. [30], lower efficiency of lower temperatures in removing $P A H \mathrm{~s}$ is due to the retention of the compound particles in the pores of biochar. These authors stated that higher process temperature should result in gradual release of water and volatile components and, in consequence, opening of pores and release of PAHs. After completing the procedure, the materials were left in the furnace to cool (ambient temperature). After cooling, the materials were placed in a desiccator, and then weighed in order to determine the mass loss.

\section{The content of dry matter, ash and total and mobile forms of trace elements in the untreated sewage sludge and in the mixtures after thermal treatment}

The dry matter content and ash determined according to the procedure described in Gondek et al. [26] and Hale et al. [28]. The total content of the studied trace elements was determined after incinerating 2 grams (weighed into quartz evaporating dishes) of the sample in a chamber furnace at $450^{\circ} \mathrm{C}$ for 12 hours. After cooling, the residue was treated with a mixture of concentrated nitric and perchloric (3:2) (v/v) acids, and then left at a room temperature for 24 hours. Then, after evaporation on a sand bath, the residue was treated with a $20 \%$ hydrochloric acid solution and heated $\left(120^{\circ} \mathrm{C}\right)$ on a sand bath for 2 hours under watch glass. After cooling, the content was transferred quantitatively to $50 \mathrm{~cm}^{3}$ flasks and filtrated through a qualitative filter [31]. The contents of $\mathrm{Cr}, \mathrm{Cu}, \mathrm{Ni}, \mathrm{Pb}, \mathrm{Zn}$ and $\mathrm{Cd}$ were determined in the obtained solutions using the ICP-OES method with the use of Perkin Elmer Optima 7300 DV apparatus.

The content of mobile forms of the studied trace elements in the untreated sewage sludge and in the mixtures, before and after thermal treatment, was determined after extraction with redistilled water. $1 \mathrm{~g}$ of an analytical sample of the materials (in four replications) was treated with $20 \mathrm{~cm}^{3}$ of redistilled water and placed in a rotary agitator (36 revolutions per minute) for 24 hours. After that time, the extract was separated from solid parts by filtering the suspension through a qualitative filter to $25 \mathrm{~cm}^{3}$ flasks. Determinations of the contents of the studied trace elements was carried out by the same method as determination of the total forms.

\section{Humic compounds of the untreated sewage sludge and mixtures after thermal treatment}

Extraction of humic acids was conducted using a $0.5 \mathrm{~mol} \cdot \mathrm{dm}^{-3} \mathrm{NaOH}$ solution (Cex) (extraction for 24 hours). Carbon of humic acids (Cha) was separated from the extract by acidifying it with sulfuric acid to $\mathrm{pH} \sim 2$. The carbon content in the individual fractions was determined by Tiurin method. The content of carbon of fulvic acids (Cfa) and non-hydrolyzing carbon ( $\mathrm{Cnh}$ ) was calculated from the difference of, respectively (1) and (2):

$$
\begin{gathered}
\mathrm{Cfa}=\mathrm{Cex}-\mathrm{Cha} \\
\mathrm{Cnh}=\mathrm{Ct}-\mathrm{Cex}
\end{gathered}
$$




\section{Ecotoxicity of the untreated sewage sludge and mixtures after thermal treatment}

Acute toxicity of the extracts $(1: 20)$ was determined based on the measurement of luminescence intensity of Vibrio fischeri bacteria. Light emission of the bacteria is a function of the luciferase enzyme system, controlled by the lux genes, and light output is related to respiratory activity. The test uses reagents ( $V$. fischeri) purchased from Strategic Diagnostics Inc. (Polish distributor, Tigret). A standard test procedure $(81.9 \%$ Screening Test) was applied in the extract samples. The samples were analyzed in Microtox ${ }^{\circledR}$ M500 analyzers [32]. The measurement of luminescence at $490 \mathrm{~nm}$ was carried out before and after $15 \mathrm{~min}$ incubation of the bacterial suspension with the studied samples, and then toxicity effect $I[\%]$ was calculated according to the equation:

$$
I=\left(1-L_{s} / L_{c}\right) \cdot 100 \%
$$

where: $I$ - toxicity [\%]; $L_{s}$ - the luminescence intensity of the studied sample; $L_{c}$ - the luminescence intensity of the control. Three replicate samples were tested.

\section{Statistical computations}

The standard deviation $(S D)$ value was calculated for the obtained results, and in order to determine the diversification within the analyzed population the coefficient of variation $(\mathrm{CV})$ was calculated as the share of standard deviation in the arithmetic mean of the analyzed properties. All statistical computations were conducted using Statistica PL package.

\section{Results and discussion}

\section{Chemical composition of the materials}

Wheat straw, sawdust, and bark, all of which were components for preparing the mixtures with sewage sludge, had a small amount of water, which was an important factor influencing the improvement of physical properties of the obtained mixtures [33].

The content of the studied trace elements in the sewage sludge was conditioned by the type of treated sewage, which finds confirmation in other authors' test results [34]. The determined contents of the trace elements in the plant materials used in the research do not deviate from contents registered by other authors in these types of materials [35].

Table 4

The content total forms of trace elements in mixtures before thermal treatment

\begin{tabular}{|c|c|c|c|}
\hline \multirow{2}{*}{ Material* } & Cr & Cu & Ni \\
\cline { 2 - 4 } & \multicolumn{3}{|c|}{$\left[\mathrm{mg} \cdot \mathrm{kg}^{-1} \mathrm{~d} . \mathrm{m}.\right]$} \\
\hline SS + B & $192 \pm 25$ & $141 \pm 12$ & $32.9 \pm 1.9$ \\
\hline SS + WS & $156 \pm 12$ & $132 \pm 8$ & $27.5 \pm 1.2$ \\
\hline SS + S & $211 \pm 12$ & $149 \pm 11$ & $32.1 \pm 2.1$ \\
\hline CV & 15 & 6 & Cd \\
\hline & Pb & {$\left[\mathrm{mg} \cdot \mathrm{kg}^{-1} \mathrm{~d} . \mathrm{m}.\right]$} \\
\cline { 2 - 4 } & $39.5 \pm 3.1$ & $941 \pm 71$ & $1.44 \pm 0.08$ \\
\hline SS + B & $25.9 \pm 2.9$ & $866 \pm 70$ & $1.18 \pm 0.06$ \\
\hline SS + WS & $31.0 \pm 3.0$ & $996 \pm 65$ & $1.26 \pm 0.06$ \\
\hline SS + S & 21 & 7 & 10 \\
\hline
\end{tabular}

* see Materials and methods. Each value represents the mean of three replicates $\pm S D$ 
As a result of thermal treatment of the prepared mixtures, diversified values of the residue were obtained, depending on plant component that was used to prepare the mixture and on the temperature of the process (Table 3). Less residue, regardless of the component added to the sewage sludge, was recorded for temperature of $600^{\circ} \mathrm{C}$, which was a result of greater losses of substances that undergo oxidation at this temperature, including non-organic compounds [36]. Thipkhunthod et al. [37] and Hossain et al. [11] also obtained varied results concerning the residue after thermal treatment of different kinds of sewage sludge. As the quoted authors stated, differences in mass loss of the pirolyzed sewage sludge can result from quantitative and qualitative differences between components, including ash content and the temperature of pyrolysis process.

Total contents of the studied trace elements determined in the untreated mixtures presented in Table 4.

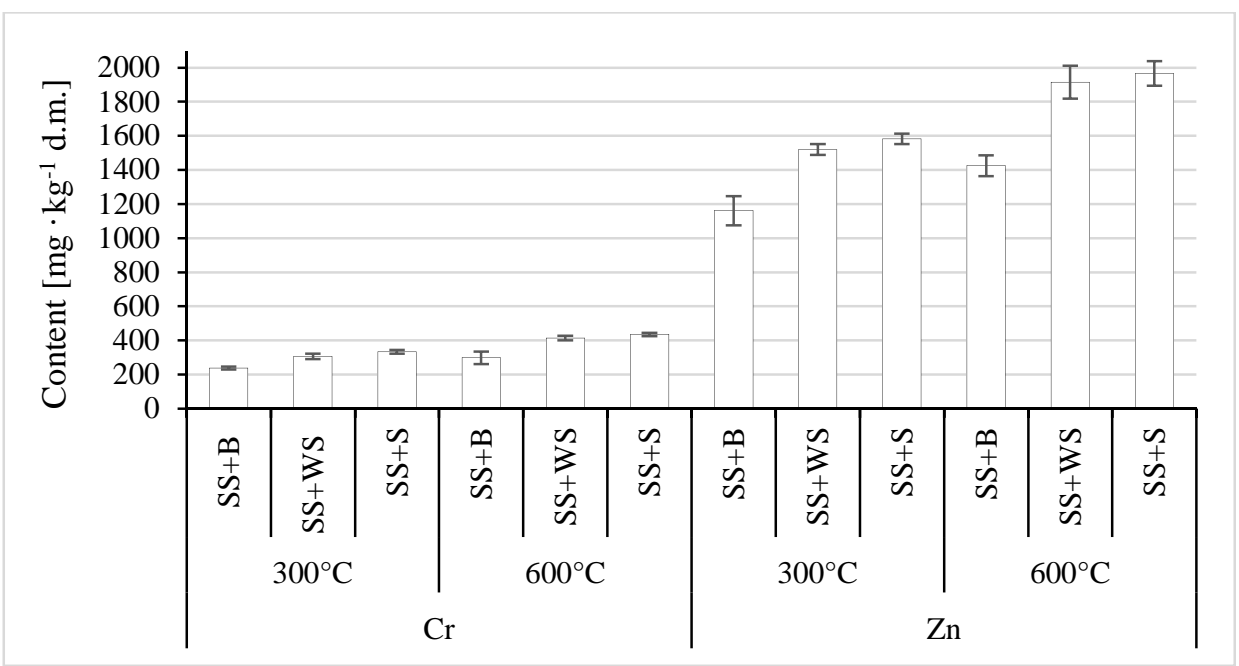

Fig. 1. The content of total forms of $\mathrm{Cr}$ and $\mathrm{Zn}$ in the studied materials. Each value represents the mean of three replicates $\pm S D$

Regardless of the addition of plant material and of element, using a higher temperature $\left(600^{\circ} \mathrm{C}\right)$ in the process caused a greater increase in the content of the studied trace elements (Figs. 1-3) in comparison to the content determined in the materials prior to the treatment (Table 4). From the studied elements, $\mathrm{Cu}$ content in the mixtures with the addition of bark and sawdust changed the most in materials after thermal treatment, regardless of the used temperature. In the case of the addition of wheat straw to the sewage sludge, the highest increase in the content (regardless of the used temperature) was recorded for $\mathrm{Cr}$ and $\mathrm{Cd}$, but at the temperature of $600^{\circ} \mathrm{C}$. The total cadmium content increased the least in the mixture of sewage sludge and bark, regardless of temperature. In the case of using a temperature of $300^{\circ} \mathrm{C}$ for thermal treatment of the materials, the lowest increase in content (in comparison to the untreated mixtures) was recorded for lead in the mixtures with the addition of wheat straw and sawdust. On the other hand, at $600^{\circ} \mathrm{C}$, the zinc content increased the least in the mixtures of sewage sludge and wheat straw and sawdust. As results from tests conducted by Hossain et al. [11] indicate, the content of trace elements increases during pyrolysis, 
depending on the used temperature, which corresponds to the mass loss. In the authors' own research, the used temperatures were 300 and $600^{\circ} \mathrm{C}$. According to Song and Guo [29], the suggested temperature, for agricultural purposes, of pyrolysis of materials should be approximately $300^{\circ} \mathrm{C}$. In research conducted by Yachigo and Sato [38], an increase in the temperature of pyrolysis caused a distinct increase in the content of zinc and copper in the obtained material, whereas no changes in the cadmium content were registered.

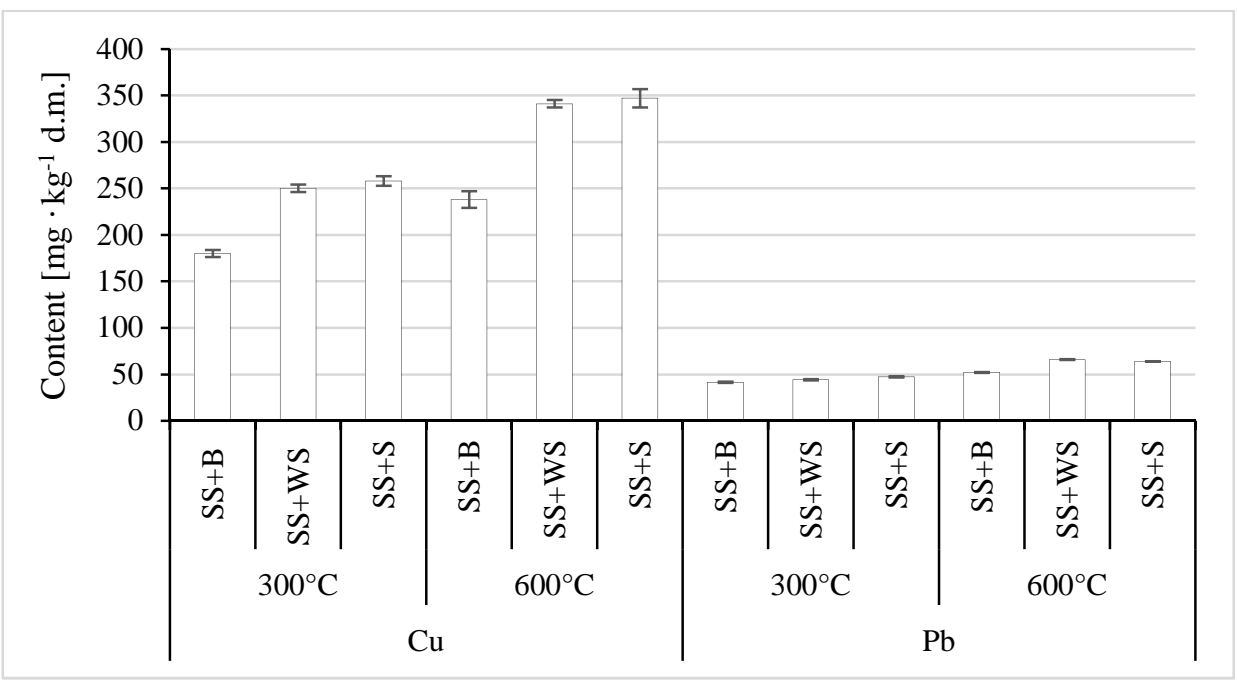

Fig. 2. The content of total forms of $\mathrm{Cu}$ and $\mathrm{Pb}$ in the studied materials. Each value represents the mean of three replicates $\pm S D$

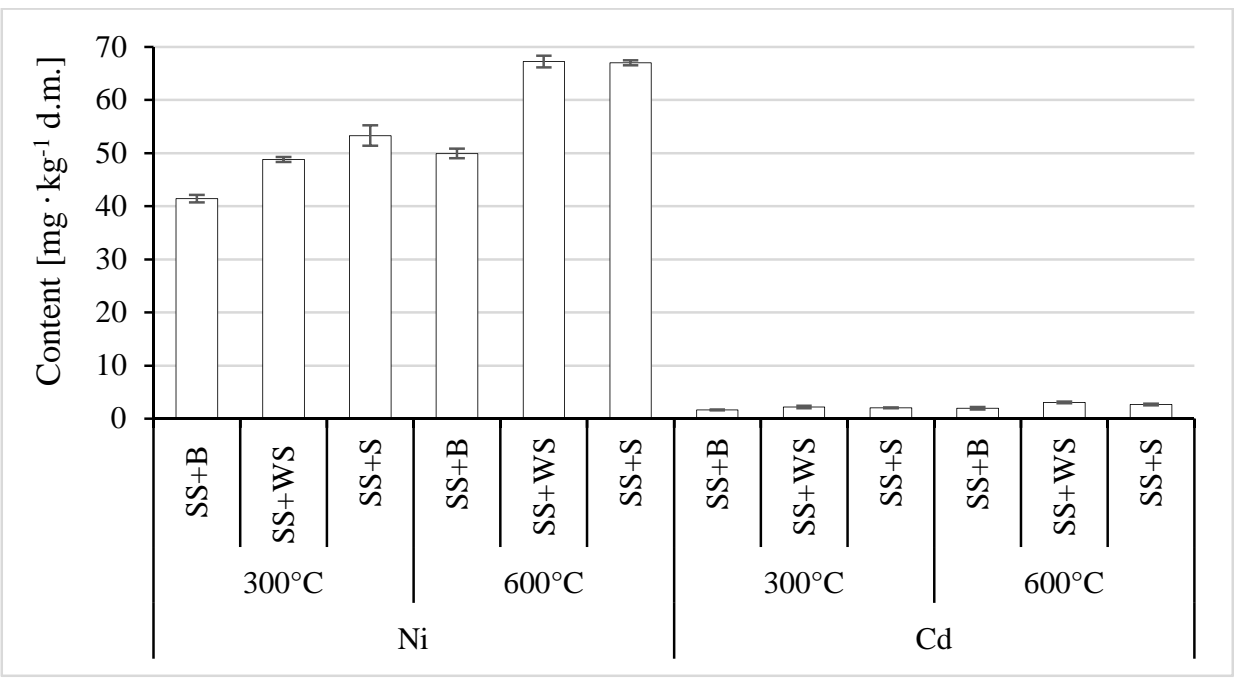

Fig. 3. The content of total forms of $\mathrm{Ni}$ and $\mathrm{Cd}$ in the studied materials. Each value represents the mean of three replicates $\pm S D$ 
As a result of conducting the process at temperatures of 300 and $600^{\circ} \mathrm{C}$, no higher differences in the content of copper and nickel forms extracted with water were detected (Figs. 5 and 6). Standard deviation values calculated for the mean indicate that the obtained differences were within determination error limits. In the case of contents of lead, zinc and cadmium forms extracted with water (Figs. 4-6), a distinct influence of temperature was found (regardless of component added to the sewage sludge), which was manifested by an increase in the content of $\mathrm{Pb}, \mathrm{Zn}$ and $\mathrm{Cd}$ forms determined at $600^{\circ} \mathrm{C}$.

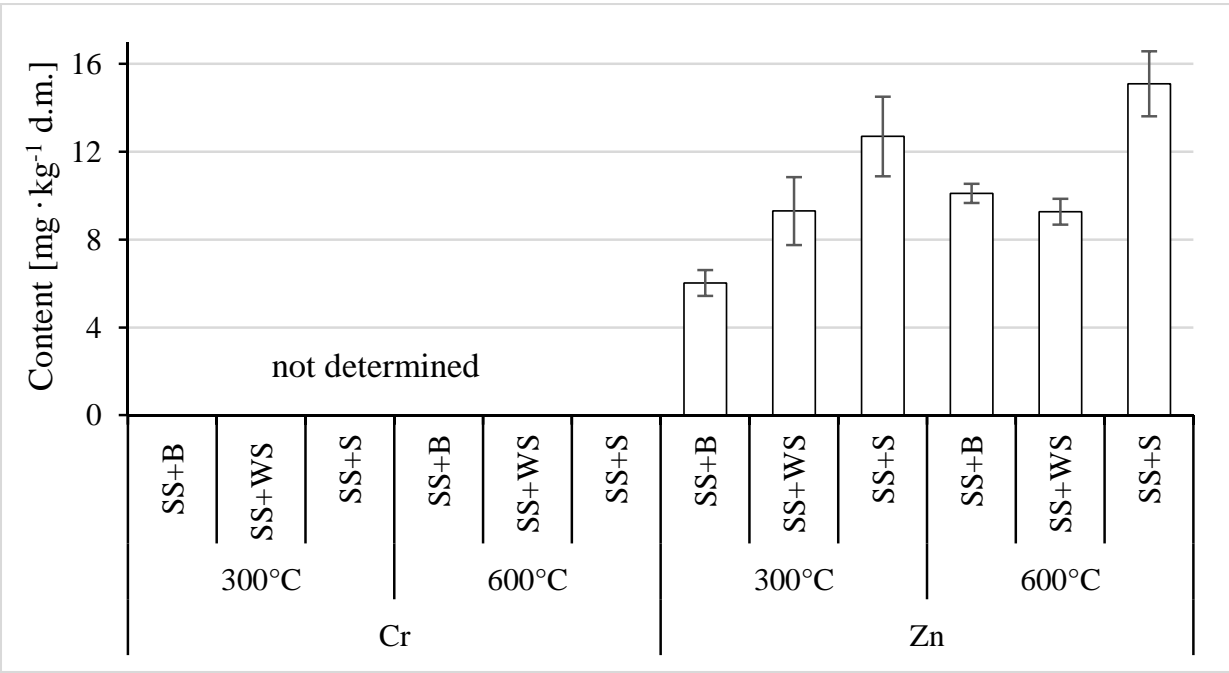

Fig. 4. The content of water soluble forms of $\mathrm{Cr}$ and $\mathrm{Zn}$ in the studied materials. Each value represents the mean of three replicates $\pm S D$

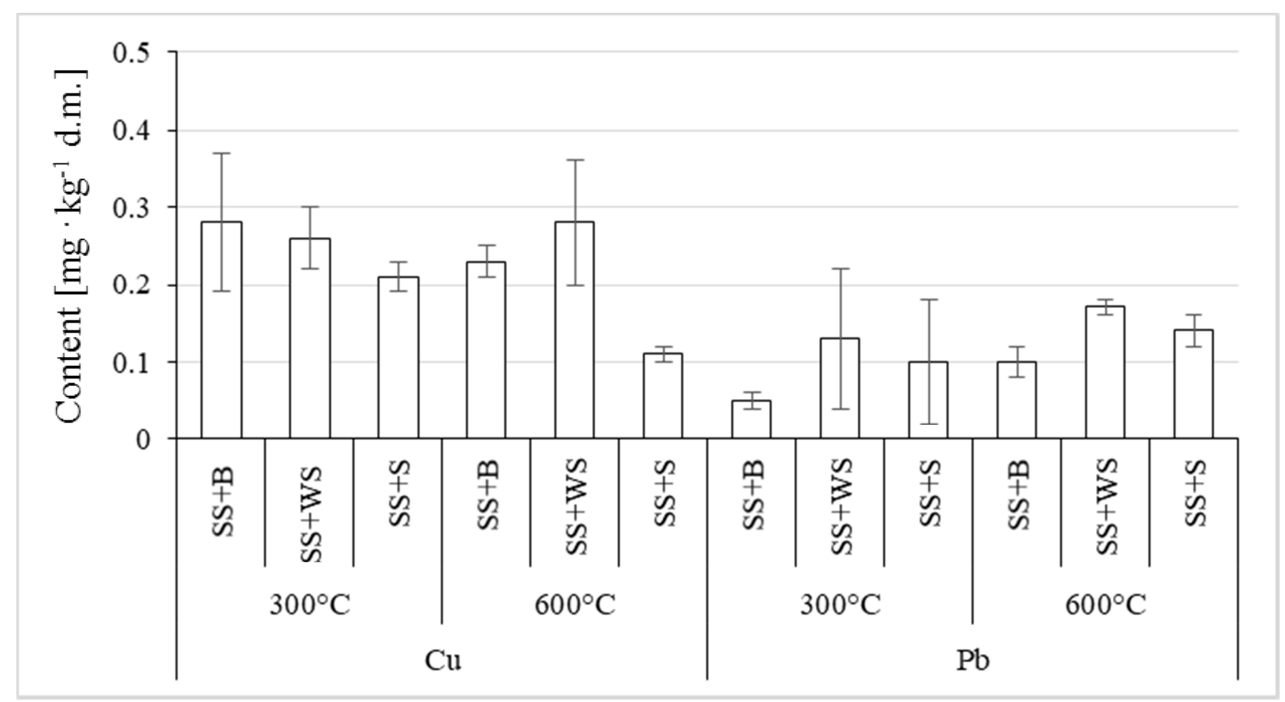

Fig. 5. The content of water soluble forms of $\mathrm{Cu}$ and $\mathrm{Pb}$ in the studied materials. Each value represents the mean of three replicates $\pm S D$ 
Only in the case of chromium no water-soluble forms were determined (Fig. 4). Based on the obtained own results, the thermal treatment process favored the increase in contents of forms of some of the studied trace elements extracted with water. It resulted from a loss of unstable aliphatic bonds and formation of more stable aromatic bonds [39, 40]. According to Hossain et al. [11], despite an increase in the total content of trace elements as a result of pyrolysis of sewage sludge, the content of bioavailable forms did not change significantly. Moreover, results from tests conducted by Mendez et al. [2] indicate that the pyrolysis process of sewage sludge at $500^{\circ} \mathrm{C}$ decreased the plant-available of $\mathrm{Cu}, \mathrm{Ni}, \mathrm{Zn}$ and $\mathrm{Pb}$, the mobile forms of $\mathrm{Cu}, \mathrm{Ni}, \mathrm{Zn}, \mathrm{Cd}$ and $\mathrm{Pb}$ and also the risk of leaching of $\mathrm{Cu}, \mathrm{Ni}$, $\mathrm{Zn}$ and $\mathrm{Cd}$. More extensive characterisation of the chemical composition and physical properties of the analysed mixtures was presented in the study of Gondek et al. [26, 41].

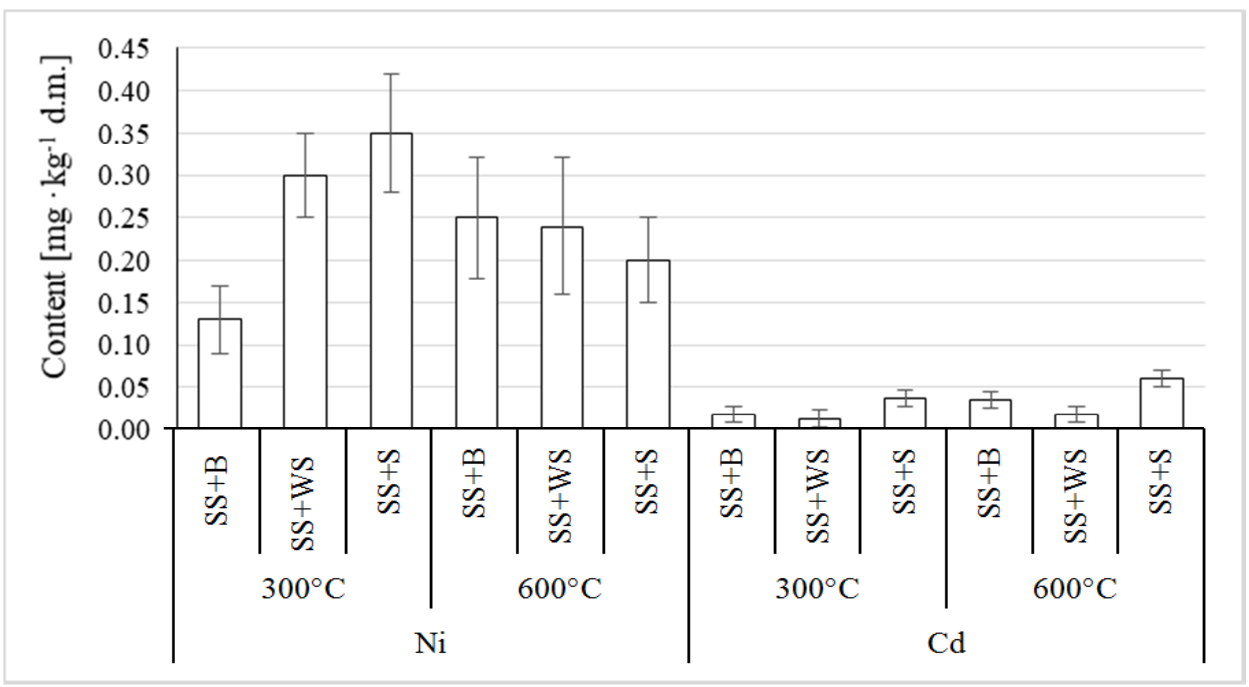

Fig. 6. The content of water soluble forms of $\mathrm{Ni}$ and $\mathrm{Cd}$ in the studied materials. Each value represents the mean of three replicates $\pm S D$

\section{Carbon content in the studied materials}

It was found that the mixtures treated at the temperature of $600^{\circ} \mathrm{C}$ did not contain humic acid carbon (Table 5).

Table 5

The share of carbon of each fraction in total carbon content in sewage sludge and mixtures sewage sludge and plant materials after thermal treatment

\begin{tabular}{|c|c|c|c|c|c|c|}
\hline \multirow{3}{*}{ Material* } & \multicolumn{2}{|c|}{ C humic acids (Cha) } & \multicolumn{2}{c|}{ C fulvic acids (Cfa) } & \multicolumn{2}{c|}{ C non-hydrolyzing (Cnh) } \\
\cline { 2 - 7 } & $300^{\circ} \mathrm{C}$ & $600^{\circ} \mathrm{C}$ & $300^{\circ} \mathrm{C}$ & $600^{\circ} \mathrm{C}$ & $300^{\circ} \mathrm{C}$ & $600^{\circ} \mathrm{C}$ \\
\cline { 2 - 7 } & \multicolumn{7}{|c|}{$\mathrm{C}$ content $[\%]$} & $96.8 \pm 0.3$ & $99.6 \pm 0.2$ \\
\hline SS + B & $1.17 \pm 0.14$ & n.d. & $2.00 \pm 0.16$ & $0.38 \pm 0.17$ & $97.1 \pm 0.6$ & $99.4 \pm 0.1$ \\
\hline SS + WS & $0.55 \pm 0.02$ & n.d. & $2.39 \pm 0.60$ & $0.56 \pm 0.09$ & 1 & $0.1 \pm 0.4$ \\
\hline SS + S & $0.50 \pm 0.11$ & n.d. & $0.91 \pm 0.02$ & $0.86 \pm 0.07$ & $98.6 \pm 0.2$ & 0 \\
\hline CV & 41 & - & 35 & 33 & & $86.5 \pm 6.5$ \\
\hline SS & \multicolumn{2}{|c|}{$4.14 \pm 0.13$} & $9.37 \pm 0.93$ & \\
\hline
\end{tabular}

\footnotetext{
* see Materials and methods; n.d. - not determined. Each value represents the mean of three replicates $\pm S D$
} 
The content of fulvic acid carbon, regardless of the component added to the sewage sludge, was higher than the content of humic acid carbon. However, using the higher temperature $\left(600^{\circ} \mathrm{C}\right)$ did not have a beneficial effect on the content of that fraction of organic matter.

The content of non-hydrolyzing carbon in the studied materials ranged from 97.2 to $99.8 \%$ of total C. Bottom values of the range concerned the content of non-hydrolyzing $\mathrm{C}$ in the mixtures treated at the temperature of $300^{\circ} \mathrm{C}$. Research results of Réveillé et al. [42] indicate that maturity has a significant impact on the carbon distribution in individual fractions of humic compounds extracted from sewage sludge. Moreover, as the quoted authors observed, substances such as lipids may be, aside from treatment technology, of significant importance in this respect. The obtained research results indicate that in consequence of using the mixture of sewage sludge and organic materials we may increase the content of the fraction of organic substances that are difficult to hydrolyze, which may be of importance not only in terms of improving the properties of soils to which these materials had been introduced, but also in terms of sequestration of $\mathrm{C}$.

\section{Vibrio fischeri response}

The research showed that the extracts prepared from the studied mixtures were non-toxic for Vibrio fischeri (Table 6). Moreover, stimulation of luminescence of the test organism was found. The extract samples showed negative mean values of toxicity. This means that luminescence intensity of $V$. fischeri increased after exposure to the extracts as a result of their lower toxicity compared with the reference medium ( $\mathrm{NaCl}$ solutions). Inhibition of luminescence of $V$. fischeri at a level of $9 \%$ was found only in extracts from the sewage sludge (SS). In the literature, the stimulatory effect of sublethal or low concentrations of toxic chemicals on organism metabolism is referred to as hormesis [43]. At this point it must be highlighted that low concentrations of trace elements in the extracts were found in the research (Figs. 4-6).

Nontoxicity of extracts from the studied materials for Vibrio fischeri

Table 6

\begin{tabular}{|c|c|c|c|c|c|c|c|}
\hline \multirow{3}{*}{$\begin{array}{c}\text { Luminescence } \\
\text { inhibition Vibrio } \\
\text { fischeri [\%] }\end{array}$} & \multicolumn{2}{|c|}{$\mathrm{SS}+\mathrm{B}^{*}$} & \multicolumn{2}{|c|}{$\mathrm{SS}+\mathrm{WS}$} & \multicolumn{2}{|c|}{$\mathrm{SS}+\mathrm{S}$} & \multirow{2}{*}{ (SS) } \\
\hline & $300^{\circ} \mathrm{C}$ & $600^{\circ} \mathrm{C}$ & $300^{\circ} \mathrm{C}$ & $600^{\circ} \mathrm{C}$ & $300^{\circ} \mathrm{C}$ & $600^{\circ} \mathrm{C}$ & \\
\hline & $-18 \pm 2$ & $-23 \pm 1$ & $-26 \pm 3$ & $-25 \pm 2$ & $-25 \pm 1$ & $-26 \pm 2$ & $9 \pm 3$ \\
\hline
\end{tabular}

* see Materials and methods; Each value represents the mean of three replicates \pm standard deviation

Hormesis has been found to be common in the widely used Vibrio fischeri luminescence bioassay [44-46]. Samples showing hormesis are currently non-toxic. Hormesis is a widespread phenomenon in the exposure to metals with luminescent bacteria, because the $V$. fischeri is generally less sensitive to metals than to plant and animal cells $[47,48]$. In the research by Shen et al. [48], a clear hormesis phenomenon was observed in all tested metals $(\mathrm{Cu}, \mathrm{Zn}, \mathrm{Cd}, \mathrm{Cr})$ at a low concentration under the condition of luminescence assay. Luminescence stimulation by exposure to zinc, cadmium, and chromium was also found in research by Christofi et al. [43], who showed an enhancement of luminescence induced by low concentrations of these metals. Stimulation of $V$. fischeri bacteria luminescence was observed in the environmental research when analyzing samples of pore water from bottom sediments and river $[49,50]$. In both cases, a low concentration 
of heavy metals in the studied samples was found. However, hormesis is rarely mentioned and accepted in mainstream toxicology [48].

\section{Conclusions}

Findings from this work showed that adding a plant component to sewage sludge will have the effect of reducing the content of trace element in those mixtures. In comparison to the content that was determined in the mixtures prior to treatment, and also in comparison to the untreated sewage sludge, using the temperature of $300^{\circ} \mathrm{C}$ caused significantly lower changes in the contents of total forms of the trace elements than using the temperature of $600^{\circ} \mathrm{C}$. The determined contents of forms of trace elements extracted with water from the thermally treated mixtures, regardless of temperature, were lower than the contents determined in the untreated sewage sludge.

Taking into account the fractional composition of humic compounds, thermal treatment of mixtures of sewage sludge and plant materials is not beneficial in terms of labile fractions, but it had a beneficial effect on stabilizing the bonds between carbon compounds in those mixtures.

Bioassays were demonstrated to be useful for detecting potentially ecotoxicological effects of biochar, not captured by the physicochemical limit values set in different biochar quality standards currently available, which do not provide guidance for application rates specific to soil or crop types. This is why ecotoxicological tests are proposed as important criteria to develop management recommendations. The trace elements extracted from the mixtures of sewage sludge and plant component will be non-toxic for Vibrio fischeri.

\section{Acknowledgements}

The research was financed by the Ministry of Science and Higher Education of the Republic of Poland.

\section{References}

[1] Agrafioti E, Bouras G, Kalderis D, Diamadopoulos E. J Anal Appl Pyrol. 2013;101:72-78. DOI:10.1016/j.jaap.2013.02.010.

[2] Méndez A, Gómez A, Paz-Ferreiro J, Gascó G. Chemosphere. 2012;89:1354-1359. DOI: 10.1016/j.chemosphere.2012.05.092.

[3] Srinivasan P, Sarmah AK, Smernik R, Das O, Farid M, Gao W. Sci Total Environ. 2015;512-513:495-505. DOI: 10.1016/j.scitotenv.2015.01.068.

[4] Wang L, Weller CL, Jones DD, Hanna MA. Biomass Bioenergy. 2008;32:573-581. DOI: 10.1016/j.biombioe.2007.12.007.

[5] Zielińska A, Oleszczuk P, Charmas B, Skubiszewska-Zięba J, Pasieczna-Patkowska S. J Anal Appl Pyrol. 2015;112:201-213. DOI: 10.1016/j.jaap.2015.01.025.

[6] Lu H, Zhang W, Wang S, Zhuang L, Yang Y, Qiu R. J Anal Appl Pyrol. 2013;102:137-143. DOI: 10.1016/j.jaap.2013.03.004.

[7] Gao N, Li J, Qi B, Li A, Duan Y, Wang Z. J Anal Appl Pyrol. 2014;105:43-48.

[8] Gascó G, Blanco CG, Guerrero F, Méndez Lázaro AM. J Anal App Pyrol. 2005;74(1-2):413-420. DOI: 10.1016/j.jaap.2004.08.007.

[9] Beesley L, Moreno-Jimenez E, Gomez-Eyles JL. Environ Pollut. 2010;158(6):2282-2287. DOI: 10.1016/j.envpol.2010.02.003. Epub 2010 Mar 12.

[10] Hossain MK, Strezov V, Chan K, Yelson PF. Chemosphere. 2010;78:1167-1171. DOI: 10.1016/j.chemosphere.2010.01.009.

[11] Hossain MK, Strezov V, Chan KY, Ziolkowski A, Nelson PE. J Environ Manage. 2011;92:223-228. DOI: 10.1016/j.jenvman.2010.09.008. 
[12] Kawano Y, Yanai J, Yamada H, Nakajima K, Yasui D, Takebe K. J Soil Sci Plant Nut. 2012;83:125-132.

[13] Fonts I, Azuara M, Gea G, Murillo MB. J Anal Appl Pyrol. 2009;85:184-191. DOI: 10.1016/j.jaap.2008.11.003.

[14] Lehmann J. Front Ecol Environ. 2007;5:381-387. DOI: 10.1890/1540-9295(2007)5[381:BITB]2.0.CO;2.

[15] Laird D, Fleming P, Wang B, Horton R, Karlen D. Geoderma. 2010;158:436-442. DOI: 10.1016/j.geoderma.2010.05.012.

[16] Paz-Ferreiro J, Gascó G, Gutiérrez B, Méndez A. Biol Fertil Soils. 2012;48(5):511-517. DOI: 10.1007/s00374-011-0644-3.

[17] Beesley L, Moreno-Jimenez E, Gomez-Eyles JL, Harris E, Robinson B, Sizmur T. Environ Pollut. 2011;159:3269-3282. DOI: 10.1016/j.envpol.2011.07.023.

[18] Melligan F, Dussan K, Auccaise R, Novotny EH, Leahy JJ, Hayes MHB, et al. Bioresource Technol. 2012;108:258-263. DOI: 10.1016/j.biortech.2011.12.110.

[19] Cely P, Gasco G, Paz-Ferreiro J, Mendez A. J Anal Appl Pyrol. 2015;111:173-182. DOI: 10.1016/j.jaap.2014.11.014.

[20] Chan KY, Xu Z. Biochar: nutrient properties and their enhancement. In: Biochar for Environmental Management: Science and Technology. 978-1-84407-658-1. London, UK: J. Lehmann \& S. Joseph, Earthscan; 2009:67-84.

[21] Oleszczuk P, Jośko I, Kuśmierz M. J Hazard Mater. 2013;260:375-382. DOI: 10.1016/j.jhazmat.2013.05.044.

[22] Liu X, Zhang A, Ji C, Joseph S, Bian R, Li L, et al. Plant Soil. 2013;373:583-594. DOI: 10.1007/s11104-013-1806-X.

[23] Oleszczuk P, Jośko I, Kusmierz M, Futa B, Wielgosz E, Ligeza S, et al. Geoderma. 2014;213:502-511. DOI:10.1016/j.geoderma.2013.08.027.

[24] Bastos AC, Prodana M, Abrantes N, Keizer JJ, Soares AMVM, Loureiro S. Ecotoxicology. 2014;23:1784-1793. DOI: 10.1007/s10646-014-1344-1.

[25] Fisher JC, Belden JB, Bidwell JR. Chemosphere. 2010;80:542-547. DOI: 10.1016/j.chemosphere.2010.04.040.

[26] Gondek K, Mierzwa-Hersztek M, Smreczak B, Baran A, Kopeć M, Mróz T, et al. Polish J Chem Technol. 2016;18(4):27-35. DOI: 10.1515/pjct-2016-0067.

[27] IBI. 2012. Standardized Product Definition and Product Testing Guidelines for Biochar that Is Used in Soil. http://www.biochar-international.org/sites/default/files/Guidelines_for_Biochar_That_Is_Used_in_Soil_ Final.pdf (accessed 14 June 2015).

[28] Hale SE, Elmquist M, Brandli R, Hartnik T, Jakob L, Henriksen T, et al. Chemosphere. 2012;87:177-184. DOI: $10.1016 /$ j.chemosphere.2011.12.015.

[29] Song W, Guo M. J Anal App Pyrol. 2012;94:138-145. DOI: 10.1016/j.jaap.2011.11.018.

[30] Guilloteau A, Nguyen ML, Bedjanian Y, Le Bras G. J Phys Chem A. 2008;112:10552-10559. DOI: $10.1021 / j p 803043$ s.

[31] Kopeć M, Gondek K, Baran A. Ecotoxicol Environ Saf. 2013;89:137-142. DOI: 10.1016/j.ecoenv.2012.11.021.

[32] MicrobicsCorporation. 1992. Microtox Manual Toxicity Testing Handbook. Carlsbad, CA, USA.

[33] Kim HW, Han SK, Shin HS. Waste Manage Res. 2003;21(6):515-526. DOI: 10.1177/0734242X0302100604.

[34] Walter J, Martinez, F, Cala V. Environ Pollut. 2006;139(3):507-514. DOI: 10.1016/j.envpol.2005.05.020.

[35] Saidur R, Abdelaziz EA, Demirbas A, Hossain MS, Mekhief S. Renew Sust Energy Rev. 2011;15:2262-2289. DOI: 10.1016/j.rser.2011.02.015.

[36] Karayildirim T, Yanik J, Yuksel M, Bockhorn H. Fuel. 2006;85:1498-1508. DOI: 10.1016/j.fuel.2005.12.002.

[37] Thipkhunthod P, Meeyoo V, Rangsunvigit P, Kitiyanan B, Siemanond K, Rirksomboon T. Chemosphere. 2006;64(6):995-962. DOI: 10.1021/ef00014a022.

[38] Yachigo M, Sato S. Leachability and vegetable absorption of sewage sludge biochar. In: Soil Processes and Current Trends in Quality Assessment. Hernandez Sariano MC, editor. Rijeka, Croatia: InTech; 2013. DOI: $10.5772 / 55123$

[39] He YD, Zhai YB, Li CTL, Yanf F, Chen L, Fan XP, et al. Environ Technol. 2010;31:567-574. DOI: 10.1080/09593330903514466.

[40] Kloss S, Zehetner F, Dellantonio A, Hamid R, Ottner F, Liedtke V, et al. J Environ Qual. 2012;41(4):990-1000. DOI: 10.2134/jeq2011.0070.

[41] Gondek K, Kopeć M, Baran A, Głąb T. J Elem. 2016;21(4):1289-1303. DOI: 10.5601/jelem.2015.20.4.1008.

[42] Réveillé V, Mansuy L, Jardé É. Org Geochem. 2003;34(4):615-627. DOI: $10.1016 / \mathrm{S} 0146-6380(02) 00216-4$. 
[43] Christofi N, Hoffmann C, Tosh L. Ecotoxicol Environ Saf. 2002;52:227-231. DOI: 10.1006/eesa.2002.2203.

[44] Fulladosa E, Murat J, Martinez M, Villaescusa I. Chemosphere. 2005;60:43-48. DOI: 10.1016/j.chemosphere.2004.12.026.

[45] Graber ER, Harel YM, Kolton M, Cytryn E, Silber A, David DR, et al. Plant Soil. 2010;337:481-496. DOI: 10.1007/s11104-010-0544-6

[46] Jaiswal AK, Elad Y, Graber ER, Frenkel O. Soil Biol Biochem. 2014;69:110-118. DOI: 10.1016/j.soilbio.2013.10.051.

[47] Cedergreen N, Blain R. Environ Pollut. 2009;157:42-48. DOI:10.2203/dose-response.13-017.Erofeeva.

[48] Shen K, Shen CH, Lu Y, Tang X, Zhang C, Chen X, et al. Biol Res. 2009;42:183-187. DOI: 10.4067/S0716-97602009000200006.

[49] Baran A, Tarnawski M. Ecotoxicol Environ Saf. 2013;98:19-27. DOI: 10.1016/j.ecoenv.2013.10.010.

[50] Augustynowicz J, Tokarz K, Baran A, Płachno B. Arch Environ Contam Toxicol. 2014;66(4):572-581. DOI: 10.1007/s00244-013-9995-0. 